\title{
Militant Antifascism: An Alternative (Historical) Reading
}

Nigel Copsey

\begin{abstract}
This article offers an alternative historical reading of militant antifascism and argues that application of the "gang" designation is overly reductionist. Whilst there is a historical connection between "gangs" and militant antifascism, and militant antifascists do engage in "gang" behaviors, a "gang" designation pays no attention to the multiplicities of militant antifascism; its transnational evolution and character; and above all, the ideological motivations of the antifascists themselves.
\end{abstract}

\section{Keywords}

Antifascism; Antifa; Militant antifascists; Anti-Fascist Action; Anti-Racist Action

First let me confess that I am not a social scientist, let alone a criminologist. My alternative reading is one of a historian of antifascism, based in the United Kingdom. ${ }^{1}$ From my perspective antifascism, even its militant form, is far too variegated and ideologically-driven a phenomenon to collapse under a common definition and understanding of "gangs". This social science

\footnotetext{
${ }^{1}$ My primary works on antifascism are Nigel Copsey, Anti-Fascism in Britain $2^{\text {nd }}$ edit. Abingdon: Routledge, 2017; and Nigel Copsey and Andrzej Olechnowicz (eds.) Varieties of Anti-Fascism: Britain in the Inter-War Period. Basingstoke: Palgrave-Macmillan, 2010.
} 
designation strikes me as excessively reductionist. I think we can all agree: Antifa has roots in radical, ideological analysis. Let us not lose sight of the fact that antifa are first and foremost militant antifascists; ideological analysis is central to understanding the reasons why antifa do what they do. When they study antifa, social scientists should embrace methodological empathy. So let us understand their behavior as it is perceived and interpreted by the militant antifascists themselves.

\section{Antifascism and Street Gangs: Some Readings from History}

As a historian, my views are naturally informed by the past. With regards to antifascism, which first manifested itself close to a century ago, this is with good reason. Indeed, as Pyrooz and Densley note, since there has been fascism there has been antifascism. And so, if the history of militant antifascism reads like a history of "gang" violence, surely we must be able to consider the relationship between "gangs" and antifascism from a historical perspective too?

Venture back to Weimar Germany. In working-class areas, gangs of youths, typically aged between 16 and 25, formed "cliques". Their origins lay in "wild hiking clubs", and were, as Eve Rosenhaft described them, "a kind of proletarian parody of the more middle-class Wandervogel movement". ${ }^{2}$ It was estimated that the numbers of these gangs ranged from 100 to 600, and possibly involved some 30,000 youths. ${ }^{3}$ What concerned the German authorities was the readiness of these "cliques" to engage in physical violence. In order to capitalize on the

\footnotetext{
${ }^{2}$ Eve Rosenhaft, Beating the Fascists? The German Communists and Political Violence, 1929-1933. Cambridge: Cambridge University Press, 1983, p. 131.

${ }^{3}$ Ibid., p. 132
} 
cultural practice of physical violence by working-class “cliques", Communists in cities like Berlin and Hamburg, intentionally recruited antifascist "shock troops" from these gangs.

Increasingly, as the Communists faced a street-level onslaught from the SA, these "cliques" were subjected to a form of politicization. Even if the younger streetfighters struggled to articulate a precise political rationale, especially in terms of their encounter with some historic moment of "revolutionary struggle", at the very least they were "sufficiently committed to the cause to know which side they were on". ${ }^{4}$

These "wild cliques" would later re-emerge during the Third Reich. In 1944 Himmler acknowledged that "In the last few years, and recently in increased numbers, gatherings of youth (cliques) have formed in all parts of the Reich."5 For Himmler, they revealed "asocial-criminal rather than political-oppositional tendencies", and yet, as historians Burleigh and Wippermann point out, "Himmler's characterization of the cliques was not entirely correct. Among them were groups and individuals who had contacts with political resistance groups, and who therefore pursued 'oppositional-political' goals." 6

Needless to say, militant antifascism was never solely a German phenomenon. The militant antifascists of the Arditi del Popolo in 1920s Italy, of which there were around 150 branches, and possibly some 20,000 activists, were drawn primarily from across the politicized Left: Socialists, Communists, anarchists and revolutionary syndicalists. ${ }^{7}$ The earliest physical force antifascists in the US also appeared in the 1920s and were Italian-Americans - anarchists, communists and other leftists. If we take the year 1927 for example, during the first five months

\footnotetext{
${ }^{4}$ Ibid., p. 159

${ }^{5}$ Quoted in Michael Burleigh and Wolfgang Wippermann, The Racial State: Germany 1933-1945. Cambridge: Cambridge University Press, 1991, p. 226.

6 Ibid.

${ }^{7}$ See Tom Behan, The Resistible Rise of Benito Mussolini. London: Bookmarks, 2003, p. 61.
} 
there were more than a dozen episodes of violent confrontation between fascist and anti-fascists in the New York metropolitan area. ${ }^{8}$ The anti-fascist folk-hero of the time was the flamboyant anarchist Carlo Tresca. He would frequently boast of having "so frightened the Fascists they stopped holding meetings in New York". 9 In the 1930s, the "Minutemen", who violently opposed Nazi activities in Newark, had been formed from the "Third Ward Gang”, a group of young Jewish working-class criminals and boxers. Whilst less obviously politicized than the Italian-American radicals, they took on responsibility for defending Newark's Jewish community from Nazi attacks. ${ }^{10}$

Jump forwards to 1980s Minneapolis where the "Baldies", a gang (or "crew") of multiracial skinheads formed Anti-Racist Action (ARA) in 1987. By the early 1990s ARA had become the largest antifascist movement in North America. This started out as a gang but it went on to politicize itself: "We were very self-critical every step of the way. But we were very clear we were a political force and organization that was very consciously anti-racist." ${ }^{11}$ Another activist explained that "During the 1990's I think it would be fair to say that ARA politicized hundreds of militants and had hundreds more gravitating to it, not necessarily part of a core, but forming the essential periphery. Around 1997 an easy estimate of ARA's numbers would be 1500-2000 people." 12

My point behind these examples is to acknowledge historical connections between militant antifascism and "gangs". But we need to make sense of this connection "empathetically" and not simply collapse one (militant antifascism) into the other (gangs). As these different

\footnotetext{
${ }^{8}$ Philip V. Cannistraro, Blackshirts in Little Italy: Italian Americans and Fascism 1921-1929. West Lafayette, IN: Bordighera Press, 1999, p.84.

${ }^{9}$ Ibid., p. 137.

${ }^{10}$ See Warren Grover, Nazis in Newark. New Brunswick: Transaction Publishers, 2003.

${ }^{11}$ Quoted in Faja, Antifa U.S.A.: A history in their own words. Independently published (7 Sept. 2017$)$, p. 13.

${ }^{12}$ Quoted in Anna Key (ed.) Beating Fascism: Anarchist Anti-Fascism in Theory and Practice. London: Kate Sharpley Library, 2006, p. 46.
} 
examples show, these historical actors did experience some form of politicization. In other words, even at the most basic level, they knew what they were fighting against, and they also knew what they were fighting for.

\section{The (Transnational) Origins of Antifa}

Let us be clear, the term "antifa" is a self-designation, in other words, a label that autonomous antifascist groups chose to apply to themselves. As a self-designation it is not just short for a militant antifascist, it also refers to a transnational movement of radical, decentralized, autonomous antifascist groups. Are we really to understand the transnational development of this autonomous social movement simply in terms of a territorial or neighbourhood "street gang"?

When a group elects to adopt the label "antifa" - a German contraction of antifaschismus - it takes on a recognised style and aesthetic: "Antifas" are usually dressed all in black, with hoodies, caps, scarfs, and often brandish a two-flag logo. This logo will typically feature the words "Anti-Fascist Action". Both the flag and the words "Anti-Fascist Action" have their historical origins in interwar Germany. The colours of the flags on the banner were originally both red, and belonged to "Anti-Fascist Action" - a Communist-sponsored attempt to establish a 'united front' between Communists and Social Democrats in 1932. The logo had originally been devised by Max Keilson and Max Gebhard of the Communist Party's Association of Revolutionary Visual Artists.

However, when looking for the origins of modern "antifa", we need only go back as far as the 1980s. In 1985 a new antifascist group was launched in London. This carried the name "Anti-Fascist Action". The choice of name, it seems, had little to do with making an obvious link 
to historical antifascism in Germany. This was not some Communist Party inititiave but an initiative that came from another radical-left faction. This faction was known as "Red Action" (hence, “Anti-Fascist Action”). Red Action had been formed by the small number of activists expelled in the early 1980s from the Trotskyite Socialist Workers' Party for their involvement in Anti-Nazi League "squadism", that is to say, violent action against the far right, and in this case the 1970s British National Front.

Although Anti-Fascist Action (AFA) declared its commitment to both physical and ideological opposition to fascism, it was, in its early days, a broad front group. AFA encompassed more moderate anti-racist community organizations that were less inclined to squadist activity. Organizationally, this early AFA was something of a mismatch; it would be 1989 before AFA relaunched as a group of dedicated militant antifascists. Not for nothing, AFA would become one of Europe's pre-eminent militant antifascist groups in the 1990s, serving as a exemplar for others (including North American antifascists). In September 1993 around twenty different antifascist groups came together in Sweden and decided to form the nationwide network "Anti-Fascist Action" (their name taken from the British group).

When Anti-Fascist Action was first launched in Britain in 1985, it projected itself as the successor to the Anti-Nazi League, the mass campaign group that had been formed to counter the British National Front in the late 1970s. In France, the electoral breakthrough of the French version of the National Front triggered the formation in Toulouse in 1984 of a militant antifascist group known as SCALP (La Section Carrément Anti Le Pen). This originally drew its activists from the (Trotskyiste/Maoist) Communist Workers' Organization and the anti-nuclear movement. In 1987 SCALP, which adopted the iconography of the native American Apaché Geronimo, pushed for greater national antifascist coordination. This resulted in the formation of 
the CNAF (La coordination nationale anti-fasciste). The CNAF bulletin, which featured the two flag logo, was titled "Action Antifasciste" (“Anti-Fascist Action”).

Over the border in Germany, reunification, and an upsurge in racist violence in the early 1990s, triggered the formation of a wave of militant antifascist groups. One of the most prominent was the Autonome Antifa (M), which was established in Göttingen in 1990. This group played a central role in the formation of a nationwide organization known as the $\mathrm{AA} / \mathrm{BO}$ network - the Antifascist Action/ Nationwide Organization. This network encompassed around a dozen or so regional "antifa" groups. The formation of this German autonomist network in turn encouraged militant antifascists in the Netherlands to form their own "Anti-Fascist Action" network in 1992.

As transnational contacts between European and North American antifascists were established, further enabled by the arrival of the internet, so the term "antifa" started circulating on the North American continent. An "antifa" forum was established by ARA activists in Toronto in the mid-1990s. A Toronto branch of ARA had originally dated from 1992 and its political perspective was informed by "anarchism, marxism, the German Autonomen, First Nations organizing, and popular culture". ${ }^{13}$ This new "antifa" forum published a magazine; it even broadcast its own show - "Radio Antifa!" - on Toronto local community radio (CKLN 88.1 FM). Meanwhile, Tom Burghardt, a researcher and antifascist activist based in San Francisco established an online E-zine "Antifa Info-Bulletin" in 1996. The anti-globalization movement would impact too. The events in Seattle in 1999 gave further impetus to direct action with antifascists from ARA defending the use of the anarchist-autonomist Black Bloc.

\footnotetext{
${ }^{13}$ See Antifa forum, Antifascism in Canada, 1996. p 37.
} 
It was from the ARA network that the self-designated "antifa" TORCH Network would emerge in 2013. This was formed by ARA-affliated groups from Chicago, Los Angeles, Texas and Indiana. By 2017 TORCH listed fourteen chapters on its website. Point Three of TORCH antifa's "Points of Unity" declared:

\footnotetext{
"We oppose all forms of oppression and exploitation. We intend to do the hard work necessary to build a broad, strong movement of oppressed people centred on the working class against racism, sexism, nativism, anti-Semitism, Islamophobia, homophobia, transphobia, and discrimination against the disabled, the oldest, the youngest, and the most oppressed people. We support abortion rights and reproductive freedom. We want a classless, free society. We intend to win!"14
}

What we have today then is a variety of militant antifascism that makes symbolic and stylistic references to the historical past, but it is not governed under the aegis of some old-style, monolithic Communist movement. Admittedly, its self-determined nature does bear a resemblance to "gang-type" organization. Typically not affiliated to any formal political party, it works non-hierarchically, often at neighbourhood level. Even so, militant antifascism is surely best approached in terms of transnational, ideologically-motivated collective action.

\section{The Practice and the Politics of Militant Antifascism}

\footnotetext{
${ }^{14}$ Quoted in Faja, Antifa U.S.A, p. 14.
} 
When using the term "militant" in relation to antifascism, I am using it as a adjective, to define or describe a specific type of antifascism, in this case, physical force anti-fascism. Yet physical force anti-fascism does not just entail hitting a fascist over the head with a plank of wood, it can involve other modes of physical resistance too, such as blocking routes, holding counterdemonstrations, picketing, and so on. Numbers mobilized can be huge (as in East London in 1936). I can recall AFA-sponsored events in the early 1990s drawing crowds of thousands. The Autonome Antifa also organized cultural events, placing a special emphasis on an agitprop cultural-political initiative known as "Art and Struggle" - visual-artistic representations of antifascism in the form of posters, brochures, theatre and exhibitions. Today, the fascist/antifascist confrontation is also being played out increasingly online, in alternative virtual spaces, which further problematizes the simple conflation with street gangs. Are we not doing militant antifascism a huge disservice if we simply reduce its multiplicities to isolated incidents of faceto-face "bashing the fash" on city streets?

This over-simplification also misses a further significant point, and this relates to its revolutionary political orientation. Militant anti-fascism is not just about physically opposing the fascists, it can, and more often than not, entails systemic ideological opposition to the capitalist state. Militant antifascists will conceive their struggle in terms of a tripartite, or three-way struggle whereby the adversaries are not only fascists but the capitalist state as well. Accordingly, militant antifascists insist, there is no point in calling on the state to ban fascism since the capitalist state is the root cause of fascism in the first place.

Britain's AFA understood fascism as an ultra-conservative doctrine, the aim of which was to intensify the violence already inherent in the capitalist state. Its physical force antifascism was deemed necessary to defend those subjugated by capitalism: the working class. In attacking 
the fascists - the most "reactionary" parts of capitalist society - blows could therefore be struck against the capitalist system as a whole. Since fascism is intrinsic to capitalism, AFA's militant antifascists declared, while capitalism survives there is no meaningful sense in which fascism can be defeated. "If you seriously oppose the fascists in a way which is effective", to quote one AFA militant, then "you are operating against the state". ${ }^{15}$ Unlike liberal antifascism, which tends to oppose fascism on moral terms, and will often make recourse to legal sanctions, militant antifascists normally strive for revolutionary change, that it to say, society's "emancipation" from capitalism.

Anti-Fascist Action in Britain stressed the primacy of the working-class struggle. For AFA, the issue that united all militant anti-fascists everywhere was their working-class orientation. During the mid-1990s, AFA made contacts with Göttingen's Autonome Antifa. Their aim was to establish a militant international anti-fascist network. But for the German antifascists, AFA's insistence on a working-class orientation became a sticking point. One of the German spokespersons declared, "building up a cult about and around the working class or labour movement" seemed "at least in Germany, absurd [...] A working class in a historical sense does not exist anymore". ${ }^{16}$ Working-class identity had been destroyed by Nazism and postwar prosperity. Any international network had to be rooted in a common ideology of antiimperialism, the German antifascists maintained. Another point of difference related to the struggle against patriarchy, which AFA considered a mere diversion. In Germany, sensitivity to "machismo" led to the creation all female groups, so-called "fantifa". These were substantive

\footnotetext{
${ }^{15}$ Fighting Talk, Magazine of Anti-Fascist Action, no. 7, p. 6.

${ }^{16}$ Quoted in Nigel Copsey, "Crossing Borders: Anti-Fascist Action (UK) and Transnational Anti-Fascist Militancy in the 1990s”. In Contemporary European History (Volume 25 (4)), November 2016, 707-727.
} 
ideological differences. How does a "gang" designation allow for a proper consideration of the role of ideology and its faultlines?

Militant antifascists in Britain during the 1990s also differed from their German equivalents in that they did not deploy the Black Bloc tactic. One of the characteristic features of the German autonomists was their appearance as a 'Schwarzer Block' at the head of demonstrations (a block of activists dressed all in black, wearing balaclavas and motorcycle helmets). This tactic supposedly served several functions. At the symbolic level its purpose was to show that autonomous antifascists did not recognize the state's monopoly on violence. On a practical level it offered protection against surveillance and police action, as well as offering protection against fascist attacks. The practice has now been widely adopted by militant antifascists across the board. In the 1990s however, militant antifascists in Britain dressed in normal casual clothing. There was not a comparable autonomist movement in Britain. Within Britain's radical-left oppositional culture, there was a strand of individual libertarianism evident in anarcho-punk, but class politics remained absolutely central to its ethos. So much so that when AFA finally disbanded in 2001, it did so as a consequence of political differences. As the far right withdrew from Britain's streets under pressure from AFA, militant antifascists now moved towards countering the far right at the ballot box, forming their own political party - the Independent Working Class Association (IWCA) in 1995:

"AFA is not a club. Militant anti-fascism is not a hobby, it is a means to an end. The means are physical opposition, the end, working-class power in working-class areas. The 
physical side has proved itself effective many times over; the new situation demands that the politics do as well."17

\section{Conclusion}

The example of the IWCA underscores my essential point that the politics behind militant antifascism really do matter. It is far too reductionist to argue that when group protest turns violent, and when there are repeat incidents of violence, it does not matter if it is a basketball team, a chess club, neo-Nazis, or antifa. The application of the "gang" label may assist with law enforcement, it might make for a more effective criminal justice system, but what does it actually tell us about why people feel it necessary to take to the streets in protest in the first place? Why violence? Why are some types of protest repertoires deemed more effective than others? Why is their fight a "three-cornered" fight?

I fully accept that violence is a basic feature of militant "physical force" antifascism, violent elements are nested within antifa, and they do engage in "gang-like" behaviors. As the International Militant Anti-Fascist Network founding statement put it the 1990s, "For militant anti-fascism to take root in working class communities it must retain the ability to out-violence the fascists." ${ }^{18}$ Make no mistake, when it comes to antifascist militancy, "force must be met with force, there is no other way". ${ }^{19}$ Yet there is also much more to militant antifascism than small squads or "gangs" of antifascists on the prowl, cruising the streets looking for fascists to "bash". The reality is that militant antifascists do ascribe politico-ideological meaning to their types of

\footnotetext{
${ }^{17}$ Quoted in Copsey, Anti-Fascism in Britain, p. 178.

${ }^{18}$ See Antifa forum, The Nature of the Beast, 1998, p. 43.

${ }^{19}$ Anti-Fascist Action, An Introduction to London AFA, 1991, p. 3.
} 
behavior, and they do so in terms of a revolutionary struggle for hearts and minds. Let me finish my alternative (historical) reading with a quote from 1990s AFA:

“The anti-fascist struggle isn't only the fight against fascism but also involves the fight FOR anti-fascism."20

Nigel Copsey is Professor (Research) in Modern History at Teesside University, UK. He has worked on fascism and antifascism for many years. He is co-editor of the journal, Fascism: Journal of Comparative Fascist Studies; co-editor of the book series Routledge Studies in Fascism and the Far Right; and is on the Executive Committee of the International Association for Comparative Fascist Studies (ComFas). His latest book is Tomorrow Belongs to Us: The British Far Right since 1967 (edited with Matt Worley).

${ }^{20}$ Quoted in Sean Birchall, Beating the Fascists: The Untold Story of Anti-Fascist Action. London: Freedom Press, p. 369. Emphasis as original. 